\title{
RECORDS OF EPIGEAL SPIDERS IN BAHÍA BLANCA IN THE TEMPERATE REGION OF ARGENTINA
}

\author{
NOELIA INÉS ZANETTI
}

\begin{abstract}
Laboratorio de Entomología Aplicada y Forense, Departamento de Ciencia y Tecnología, Universidad Nacional de Quilmes, Roque Sáenz Peña 352, Bernal (1876), Prov. Buenos Aires, Argentina / Cátedra de Parasitología Clínica, Departamento de Biología, Bioquímica y Farmacia, Universidad Nacional del Sur, San Juan 670, Bahía Blanca
\end{abstract} (8000), Prov. Buenos Aires, Argentina. E-mail: <noeinesz@yahoo.com.ar>

Recibido: 05/03/2015; aceptado: 28/10/2015

\begin{abstract}
Zanetti, N. I. 2016. Records of epigeal spiders in Bahía Blanca, in the temperate region of Argentina. Acta Zoológica Mexicana (n. s.), 32(1): 32-44.
\end{abstract}

\begin{abstract}
Ecological surveys of diversity and seasonal patterns of spiders in relation with cadavers have rarely been conducted, despite the high potential species diversity and abundance of spiders. The composition, abundance, guilds and seasonality of the spiders of Bahía Blanca, in the temperate region of Argentina were analysed. The study was performed in a semi-rural area between 2010 and 2011, using pitfall traps that were checked daily during $168 \pm 7$ days in winter, 38 days in spring, 30 days in summer, and 71 days in autumn. A total of 972 spiders were recorded belonging to 22 families and 65 species/morphospecies. The most abundant families were: Lycosidae, Zodariidae, Thomisidae, Theridiidae and Salticidae. The guild with more specimens was represented by ground hunters followed by specialists and ambush hunters, and the guild with the greatest number of species corresponded also to the ground hunters. Considering all specimens, adults prevailed with respect to juveniles, and males were more abundant than females. The more abundant species were Leprolochus birabeni, Steatoda sp. 1, Thomisidae sp. 33, Thomisidae sp. 32, Ostearius melanopygius and Metaltella simoni.
\end{abstract}

Key words: Araneae, diversity, guilds, pitfall traps, taxocenosis.

\section{INTRODUCTION}

Spiders are a diverse, widely distributed group in all terrestrial ecosystems and even freshwater (Turnbull 1973; Foelix 2011). At the trophic level, the spiders are important generalist predators due to their abundance, biomass, species diversity and life strategies. Their feeding habits influence the density and activity of detritivores and fungivores, affecting the litter decomposition process (Wise et al. 1999; McNabb et al. 2001), and they are a key factor to the mortality of crop pest insects (Liljesthröm et al. 2002).
Zanetti, N. I. 2016. Registros de arañas epigeas en Bahía Blanca, en la región templada de Argentina. Acta Zoológica Mexicana (n. s.), 32(1): 32-44.

RESUMEN. A pesar del alto potencial de la diversidad de especies y abundancia de arañas, raramente han sido conducidos censos ecológicos de la diversidad y de los patrones estacionales de arañas en relación con cadáveres. Se analizó la composición, abundancia, gremios y estacionalidad de las arañas de Bahía Blanca, en la región templada de Argentina. El estudio se realizó en un área semi-rural entre 2010 y 2011, usando trampas de caída que se revisaron diariamente durante $168 \pm 7$ días en invierno, 38 días en primavera, 30 días en verano, y 71 días en otoño. Se registraron un total de 972 arañas pertenecientes a 22 familias y 65 especies/morfo-especies. Las familias más abundantes fueron: Lycosidae, Zodariidae, Thomisidae, Theridiidae y Salticidae. El gremio con más especímenes estuvo representado por las cazadoras del suelo seguidas por las especialistas y por las cazadoras por emboscada, y el gremio con el mayor número de especies corresponde también al de las cazadoras del suelo. Considerando todos los especímenes, los adultos prevalecieron respecto a los juveniles, y los machos fueron más abundantes que las hembras. Las especies más abundantes fueron Leprolochus birabeni, Steatoda sp. 1, Thomisidae sp. 33, Thomisidae sp. 32, Ostearius melanopygius y Metaltella simoni.

Palabras clave: Araneae, diversidad, gremios, trampas pitfall, taxocenosis.

A cadaver can represent a trophic and/or reproductive resource, among others, to the associated fauna. Most scavenger species are insects, belong to the orders Coleoptera, Diptera and Hymenoptera, but also arthropods such as spiders (Araneae), millipedes (Diplopoda), centipedes (Chilopoda) and isopods (Isopoda), are commonly associated with that resource and/or ephemeral habitats, due to their predatory or saprophagous habits (Norris 1965; Seastedt et al. 1981; Keh 1985; Smith 1986; Lord 1990; Catts \& Goff 1992). Considering the ecological role of the cadaveric entomofauna, such arthropods are regarded as adventitious or accidentals species, that is, those which 
use the cadaver as an extension of their own normal habitat (Catts \& Goff 1992; Goff 2009). In forensic cases, the presence of spiders can confirm the compatibility of the specimens with the environment (Garcia Rojo et al. 2009) and, together with other opportunistic insects, could provide clues about the type and location of the crime scene (Chin et al. 2011).

Several factors can influence the abundance, distribution and composition of spiders, such as: the type and structure of the vegetation (Scheidler 1990; Rubio et al. 2008); the type of habitat (Hatley \& MacMahon 1980; Uetz 1991); the pattern of land use (Weeks \& Holtzer 2000); seasonality (Lubin 1978; Sudhikumar et al. 2005; Mineo et al. 2010); climatic conditions (Crouch \& Lubin 2000; Kwon et al. 2014); amongst others. The latter are considered environment indicators (Clausen 1986; Maelfait et al. 1990; Willett 2001; Pinkus-Rendón et al. 2006; Tsai et al. 2006). Certain species are associated to environments with a certain degree of disturbance. Some of them are related to urban environments and can be found inside homes or in the peridomicile, and are indicators of anthropic impact (Durán-Barrón et al. 2009; Greene et al. 2009; Lima Silveira 2009; Silva de Miranda \& Ponce Leão Giupponi 2011; Desales-Lara et al. 2013; Cramer 2015). Other species can disperse and/or broaden their geographic location, adapting to new environments and becoming introduced or invasive species that usually displace native ones, eventually resulting in a loss of biodiversity, due to human activity (Taylor \& Doran 2001). Therefore, because of farming and cattle breeding activity, the anthropic action has caused changes in the ecosystems (Barnes et al. 1998), modifying populations, species distribution, structure and functioning of communities, and even more leading to eventual extinctions (Meffe \& Carroll 1994).

In Argentina, census or studies of the community or different patterns of spiders were performed with different crops and in different places (Liljesthröm et al. 2002; González et al. 2009; Armendrano \& González, 2010, 2011a, b; Almada et al. 2012; Avalos et al. 2013). Also, spiders associated with other ecosystems of Argentina were studied under different conditions (Avalos et al. 2007; Rubio \& Moreno 2010; Pompozzi et al. 2011).

The purpose of this study was to know and characterize the composition, diversity, abundance and seasonality of the epigeal spiders of a semi-rural area of Bahía Blan$\mathrm{ca}$, in the temperate region of Argentina, using the data obtained from a cadaveric decomposition and succession study, which contributed to the analysis of the coleopterofauna of forensic interest of the area.

\section{MATERIALS AND METHODS}

The study was conducted in natural fields $\left(38^{\circ} 41^{\prime} 52^{\prime \prime} \mathrm{S}\right.$, $62^{\circ} 14^{\prime} 47^{\prime \prime} \mathrm{W}, 51$ m.a.s.1.), in 4 randomly selected plots, of approximately $20 \times 30 \mathrm{~m}$, located at $300-500 \mathrm{~m}$ from buildings and at $100 \mathrm{~m}$ from a branch of the Napostá stream, enclosed by Populus alba L. 1753 and Tamarix sp. plantations (Fig. 1). The rest of the vegetation was dominated by Eucalyptus globulus Labill. 1800, Prosopis alpataco Phil. 1862, Chenopodium quinoa Willd. 1797 subsp. melanospermum Hunz. 1943, and pastures (Fig. 1). The study area is located within the Pampa biogeographic province (Morrone 2002). The climate is continental warm and sub-humid (Campo de Ferreras et al. 2004; Campo \& Zapperi 2010) with high thermal and rainfall variability through the year. According to Köppen, it can be classified as "pampeano", because in the warmer season the average temperature exceeds $22{ }^{\circ} \mathrm{C}$, and there is no dry season. The annual average rainfall is $600 \mathrm{~mm}$, but there are variations in the area (Gil et al. 2008; Campo et al. 2009; Gabella et al. 2010). The maximum and minimum average temperature, and accumulated rainfalls recorded during the study periods were: $20.2{ }^{\circ} \mathrm{C}, 7^{\circ} \mathrm{C}$ and $19.1 \mathrm{~mm}$, respectively (winter); $23.3^{\circ} \mathrm{C}, 11.6^{\circ} \mathrm{C}$ and 40.3 $\mathrm{mm}$, respectively (spring); $27.4^{\circ} \mathrm{C}, 15.8^{\circ} \mathrm{C}$ and $35.1 \mathrm{~mm}$, respectively (summer); and $18.2^{\circ} \mathrm{C}, 6.8^{\circ} \mathrm{C}$ and $18.3 \mathrm{~mm}$, respectively (autumn). These values were calculated from data provided by the CERZOS-CONICET weather station.

The methodology used was part of a cadaveric decomposition and succession study which contributed to the analysis of the coleopterofauna of forensic interest (Zanetti et al. 2014). Samplings were carried out every season in selected plots, starting in winter 2010 and finishing in spring 2011. The average length (Mean \pm SE) of each experiment (total time to cadaver decomposition) was: $168 \pm 7$ days (winter), 39 days (spring), 31 days (summer), and 72 days (autumn). In the selected plots, vegetation was cut at $4-5 \mathrm{~cm}$ of soil brim. Then, in three of the four plots we placed a cage of wire mesh containing a pig cadaver. Six pitfall traps were installed surrounding each cage. In the remainder plot six traps with the same disposition were used as control. The pitfall traps were made from plastic containers of $500 \mathrm{~mL}$ volume and 8.5 $\mathrm{cm}$ diameter, each buried to the rim of the soil. Each trap 


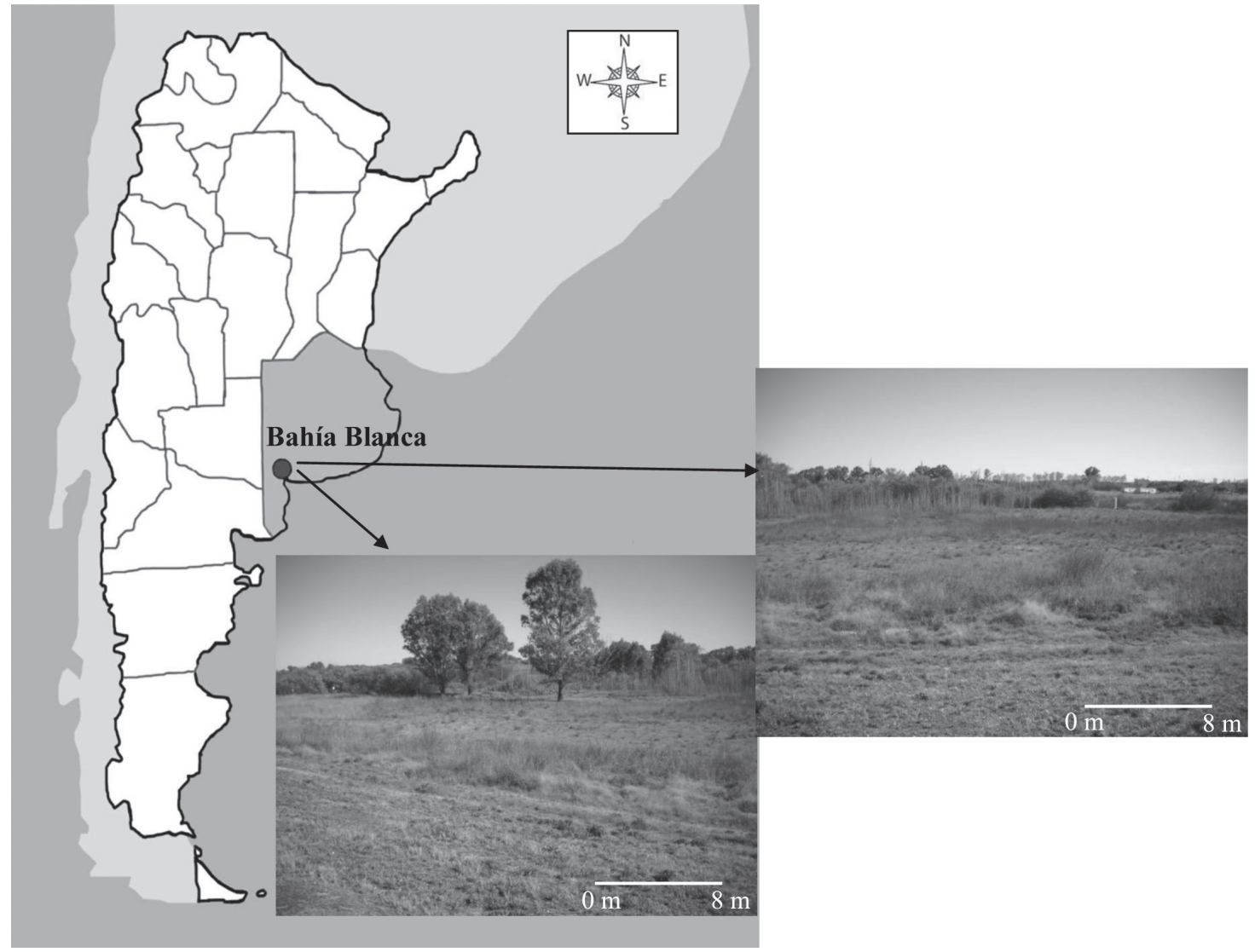

Figure 1. Map of Argentina with the location of Bahía Blanca (point), study area (arrows) and vegetation (Chenopodium quinoa subsp. melanospermum, pastures, and plantations of Populus alba, Tamarix sp. and Eucalyptus globulus, can be seen).

had two containers, one inside the other: the inner container had a solution of $90 \%$ distilled water and $10 \%$ coolant. The outer container remained buried in the ground while the solution with the arthropods was filtered with a plastic funnel and a piece of fine mesh cloth, according to Zanetti (2013). The pitfall traps and cadavers were examined daily between 9:00 and 12:00 AM, during experiment time. I followed the criterion established by Centeno et al. (2002) to define the stages of decomposition. The biological material collected was transferred to a plastic container with $70 \%$ ethanol for later determination in the laboratory and storage.

The adult specimens were determined to family and species level according to Schiapelli \& Gerschman de Pikelin (1963), Goloboff (1995), Ramirez (1999), Ferretti et al. (2010), and validated with World spider Catalog (2015), and when it was not possible, they were separated into morphospecies; juveniles were only identified to family level due to the absence of genitalia and the identification at level species the adults specimens are necessary.
Relative abundance of each family, species, state of development of specimens and seasonal abundance was estimated as: $\mathrm{RA}=(n i(100) / N)$, where $n i$ is the number of specimens collected at each site and $N$ is the total of specimens collected at the site (Flórez-D. 1998). Species richness (S) was considered as the number of species per family and per season. Density of each family and species was calculated per week. Diversity per season was assessed and compared with the Shannon Index $\left(H^{\prime}\right)$, in a binary logarithm scale, and the species evenness using the $J$ (Pielou) index $\left(J^{\prime}=H^{\prime} / H^{\prime}\right.$ max $)$. To determine if the environment has been enough sampled was used the estimator CHAO 1 (Colwell \& Coddington 1994): $\mathrm{S} 1=\operatorname{Sobs}+\left(a^{2} / 2 b\right)$, where Sobs is the number of species/morphospecies observed in the study area, $a$ is the number of species/morphospecies with one individual in the study area and $b$ is the number of species/morphospecies with two individuals in the study area. For this analysis was used the EstimateS 9.1.0 version (Colwell 2013). 
Spiders were grouped into eight guilds after Cardoso et al. (2011) to see if families may have similar ecological roles and for future studies of ecological change in the area. The specimens collected were deposited in the collection of Laboratorio de Zoología de Invertebrados II, Universidad Nacional del Sur, Bahía Blanca, Argentina.

\section{RESULTS}

A total of 972 spiders were collected, belonging to 22 families and 65 species/morphospecies (20 of them were identified to species level) and, 189 individuals (19.44\%) were identified at family level because they were juve- niles. The most abundant families were: Lycosidae $(n=$ $254,26.13 \%)$, Zodariidae $(n=162,16.67 \%)$, Thomisidae $(n=149,15.33 \%)$, Theridiidae $(n=74,7.61 \%)$ and Salticidae ( $n=59,6.07 \%)$, amounting to $71.81 \%$ of the total of the collected individuals (Table 1). Lycosidae, Thomisidae and Theridiidae were more abundant in spring; Zodariidae and Salticidae were more abundant in summer followed by spring. Some families were only found in one season (Table 1).

All the families with exception of Theraphosidae ( $n$ $=5,0.51 \%)$, Actinopodidae $(n=7,0.72 \%)$ and Nemesiidae $(n=11,1.13 \%)$, because they live in burrows, were grouped into eight guilds (Table 2). The greatest number of individuals was represented by ground hunters $(n=$

Table 1. Density of spiders of each family and species/morphospecies per week during each season, and absolute and relative abundance of them. Juveniles were not included in the species/morphospecies analysis.

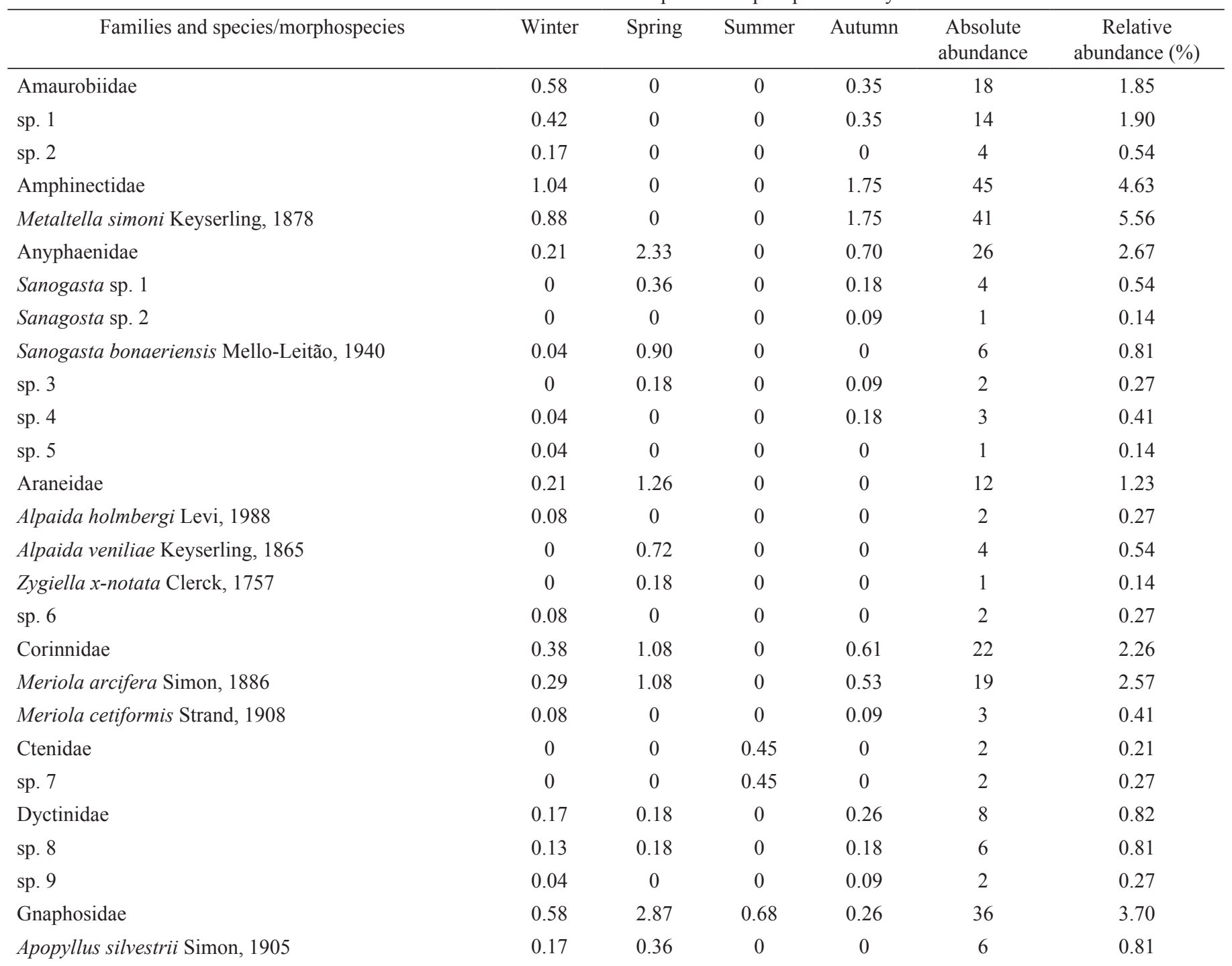


Table 1. Continue.

\begin{tabular}{|c|c|c|c|c|c|c|}
\hline Families and species/morphospecies & Winter & Spring & Summer & Autumn & $\begin{array}{c}\text { Absolute } \\
\text { abundance }\end{array}$ & $\begin{array}{c}\text { Relative } \\
\text { abundance (\%) }\end{array}$ \\
\hline Camillina chilensis Simon, 1902 & 0.33 & 1.95 & 0 & 0.09 & 20 & 2.71 \\
\hline Echemoides argentinus Mello- Leitão, 1940 & 0 & 0 & 0.68 & 0 & 3 & 0.41 \\
\hline Gnaphosidae sp. 10 & 0 & 0.36 & 0 & 0 & 2 & 0.27 \\
\hline Gnaphosidae sp. 11 & 0 & 0.18 & 0 & 0 & 1 & 0.14 \\
\hline Gnaphosidae sp. 12 & 0.04 & 0 & 0 & 0 & 1 & 0.14 \\
\hline Linyphiidae & 1.13 & 1.97 & 0.68 & 1.23 & 55 & 5.66 \\
\hline Ostearius melanopygius O. P.-Cambridge, 1879 & 0.92 & 1.62 & 0.68 & 0.96 & 45 & 6.10 \\
\hline Moyosi rugosa Millidge, 1991 & 0.13 & 0 & 0 & 0.09 & 4 & 0.54 \\
\hline Linyphiidae sp. 13 & 0 & 0 & 0 & 0.09 & 2 & 0.27 \\
\hline Linyphiidae sp. 14 & 0.04 & 0 & 0 & 0.09 & 1 & 0.14 \\
\hline Lycosidae & 5.95 & 12.18 & 6.58 & 1.26 & 254 & 26.13 \\
\hline sp. 15 & 0.17 & 1.44 & 0 & 0 & 12 & 1.63 \\
\hline sp. 16 & 0.04 & 1.44 & 0 & 0 & 9 & 1.22 \\
\hline sp. 17 & 0.17 & 0.54 & 0 & 0 & 7 & 0.95 \\
\hline sp. 18 & 0.29 & 0.72 & 2.26 & 0.09 & 22 & 2.98 \\
\hline sp. 19 & 0 & 0 & 0.23 & 0 & 1 & 0.14 \\
\hline sp. 20 & 0 & 0.18 & 0.23 & 0 & 2 & 0.27 \\
\hline sp. 21 & 0 & 0 & 0.23 & 0 & 1 & 0.14 \\
\hline sp. 22 & 0.17 & 0 & 0 & 0 & 4 & 0.54 \\
\hline Lycosa thorelli Keyserling, 1877 & 0.92 & 0.72 & 0 & 0 & 26 & 3.52 \\
\hline Hogna bivittata Mello-Leitão, 1939 & 0.90 & 1.08 & 0.45 & 0.09 & 30 & 4.07 \\
\hline Miturgidae & 0 & 0.18 & 0 & 0 & 1 & 0.10 \\
\hline Macerio sp. & 0 & 0.18 & 0 & 0 & 1 & 0.14 \\
\hline Philodromidae & 0.08 & 0.36 & 0 & 0 & 4 & 0.41 \\
\hline Paracleocnemis sp. & 0.08 & 0 & 0 & 0 & 2 & 0.27 \\
\hline Salticidae & 1.13 & 2.51 & 2.03 & 0.79 & 59 & 6.07 \\
\hline sp. 23 & 0.75 & 1.44 & 0.45 & 0.35 & 32 & 4.34 \\
\hline sp. 24 & 0.04 & 0.36 & 0 & 0 & 3 & 0.41 \\
\hline sp. 25 & 0.04 & 0.36 & 0 & 0 & 3 & 0.41 \\
\hline sp. 26 & 0 & 0 & 0 & 0.09 & 1 & 0.14 \\
\hline sp. 27 & 0.13 & 0 & 0 & 0 & 3 & 0.41 \\
\hline Segestriidae & 0.04 & 0 & 0 & 0 & 1 & 0.001 \\
\hline Titanoecidae & 0 & 2.33 & 0.68 & 0 & 16 & 1.65 \\
\hline Goeldia sp. & 0 & 1.95 & 0.68 & 0 & 14 & 1.90 \\
\hline Theridiidae & 0.54 & 3.77 & 1.58 & 2.89 & 74 & 7.61 \\
\hline Steatoda sp. 1 & 0.33 & 3.41 & 1.13 & 2.63 & 62 & 8.40 \\
\hline Steadota sp. 2 & 0 & 0 & 0.45 & 0 & 2 & 0.27 \\
\hline Guaraniella sp. & 0.08 & 0 & 0 & 0 & 2 & 0.27 \\
\hline sp. 28 & 0 & 0.18 & 0 & 0 & 1 & 0.14 \\
\hline sp. 29 & 0 & 0 & 0 & 0.18 & 2 & 0.27 \\
\hline sp. 30 & 0.08 & 0 & 0 & 0 & 2 & 0.27 \\
\hline sp. 31 & 0.04 & 0 & 0 & 0 & 1 & 0.14 \\
\hline
\end{tabular}


Table 1. Continue.

\begin{tabular}{|c|c|c|c|c|c|c|}
\hline Families and species/morphospecies & Winter & Spring & Summer & Autumn & $\begin{array}{c}\text { Absolute } \\
\text { abundance }\end{array}$ & $\begin{array}{c}\text { Relative } \\
\text { abundance }(\%)\end{array}$ \\
\hline Thomisidae & 3.70 & 5.92 & 0.68 & 2.1 & 149 & 15.33 \\
\hline sp. 33 & 2.08 & 1.10 & 0 & 0 & 56 & 7.59 \\
\hline sp. 34 & 0.08 & 0.40 & 0 & 0 & 4 & 0.54 \\
\hline Zodariidae & 3.33 & 4.13 & 4.52 & 3.41 & 162 & 16.67 \\
\hline sp. 36 & 0 & 0 & 0.23 & 0 & 1 & 0.14 \\
\hline Cybaeodamus ornatus Mello-Leitão, 1938 & 0.08 & 0.45 & 0.90 & 0.53 & 14 & 1.90 \\
\hline Leprolochus birabeni Mello-Leitao, 1942 & 2.67 & 3.61 & 2.03 & 2.71 & 120 & 16.26 \\
\hline Actinopus sp. & 0 & 0 & 1.35 & 0 & 6 & 0.81 \\
\hline Nemesiidae & 0.33 & 0 & 0.23 & 0.18 & 11 & 1.13 \\
\hline Acanthogonatus centralis Goloboff, 1995 & 0.29 & 0 & 0.21 & 0.21 & 10 & 1.36 \\
\hline Theraphosidae $^{*}$ & 0.04 & 0 & 0.23 & 0.26 & 5 & 0.51 \\
\hline Catumiri argentinensis Mello-Leitão, 1941 & 0.04 & 0 & 0 & 0.26 & 4 & 0.54 \\
\hline
\end{tabular}

${ }^{*}$ Grammostola doeringi Holmberg, 1881 was not included because was found only as juvenile (1 individual in summer).

Table 2. Guilds, specific richness (S) of each family and relative abundance (\%) of each guild.

\begin{tabular}{|c|c|c|c|}
\hline Guild & Family/Subfamily & Specific richness (S) & Relative abundance (\%) \\
\hline Ambush hunters & Thomisidae & 5 & 15.33 \\
\hline \multirow[t]{3}{*}{ Ground hunters } & Amphinectinae & 1 & 37.24 \\
\hline & Gnaphosidae & 6 & \\
\hline & Lycosidae & 10 & \\
\hline \multirow[t]{4}{*}{ Other hunters } & Anyphaenidae & 6 & 9.47 \\
\hline & Ctenidae & 1 & \\
\hline & Philodromidae & 1 & \\
\hline & Miturgidae & 1 & \\
\hline \multirow[t]{2}{*}{ Sheet web } & Amaurobiidae & 2 & 7.51 \\
\hline & Linyphiidae & 4 & \\
\hline \multirow[t]{3}{*}{ Space web } & Dictynidae & 2 & 10.08 \\
\hline & Titanoecidae & 1 & \\
\hline & Theridiidae & 7 & \\
\hline
\end{tabular}


$362 ; 37.24 \%)$, followed by specialists $(n=162 ; 16.67 \%)$ and ambush hunters $(n=149 ; 15.33 \%)$. The rest of the guilds had percentages lower than $10.08 \%$ (Table 2). The guild of ground hunters also exhibited the greatest species richness $(S=20)$.

Adults $(n=738,75.93 \%)$ predominated over juveniles $(n=234,24.07 \%)$, and males were more abundant $(n=$ $523,70.87 \%$ ) than females. When seasonality was evaluated, males were the most abundant in all seasons. Figure 2 shows the relative abundance of adults and juveniles of each family. Lycosidae was the family most strongly represented by juveniles ( $n=140 ; 55.12 \%)$.

The specific richness $(S)$ registered was of 65 species. The total specific diversity and the evenness were high in all seasons (Fig. 3). The families with the greatest number of species were Lycosidae $(S=10)$ and Theridiidae $(S=7)$ (Table 2). The former had the greatest number of species in winter $(S=7)$ and spring $(S=8)$, and the latter in winter $(S=4)$ (Table 1). The most abundant species (Table 1) were Leprolochus birabeni Mello-Leitao, 1942 (Zodariidae) $(n=120)$, Steatoda sp. 1 (Theridiidae) $(n=62)$, Thomisidae sp. $33(n=56)$, Thomisidae sp. 32 $(n=47)$, Ostearius melanopygius O. P.-Cambridge, 1879 (Linyphiidae) $(n=45)$ and Metaltella simoni Keyserling, 1878 (Amphinectidae) $(n=41)$. Leprolochus birabeni (Zodariidae) was almost constant in number of individuals between seasons; Steatoda sp. 1 was more abundant

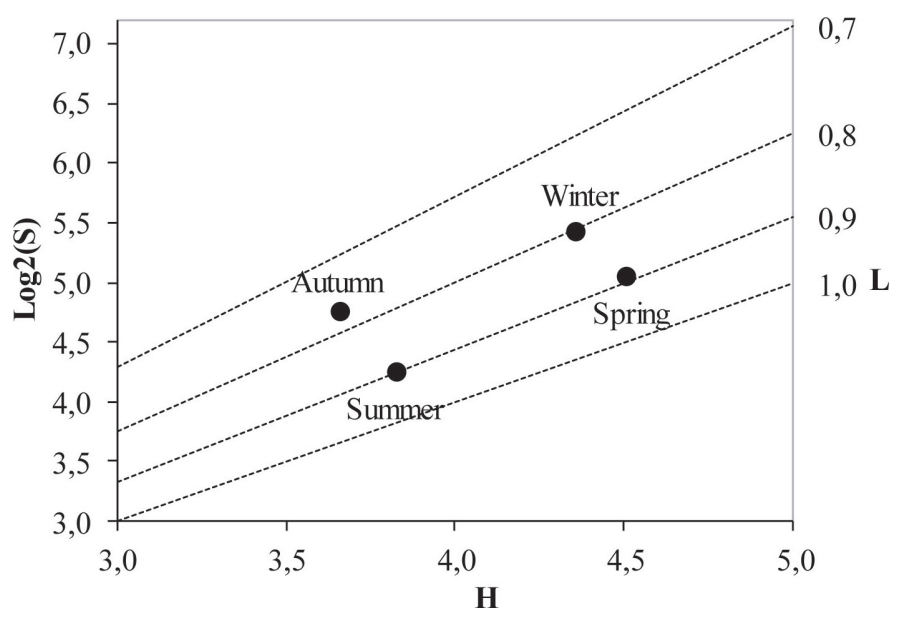

Figure 3. Specific diversity $(H)$ and evenness $(L)$ per season.

in spring followed by autumn; Thomisidae sp. 33 had the greatest number of individuals in winter; Thomisidae sp. 32 and $O$. melanopygius were more abundant in spring; and Metaltella simoni was more abundant in autumn (Table 1). For the more abundant families the relative abundance of Lycosidae was due to Lycosa thorelli Keyserling, 1877 and Hogna bivitatta Mello-Leitão, 1939; for Thomisidae it was due to Thomisidae sp. 1, and for Theridiidae, it was due to Steatoda sp. 1. During summer and spring the relative abundance of Zodariidae was due

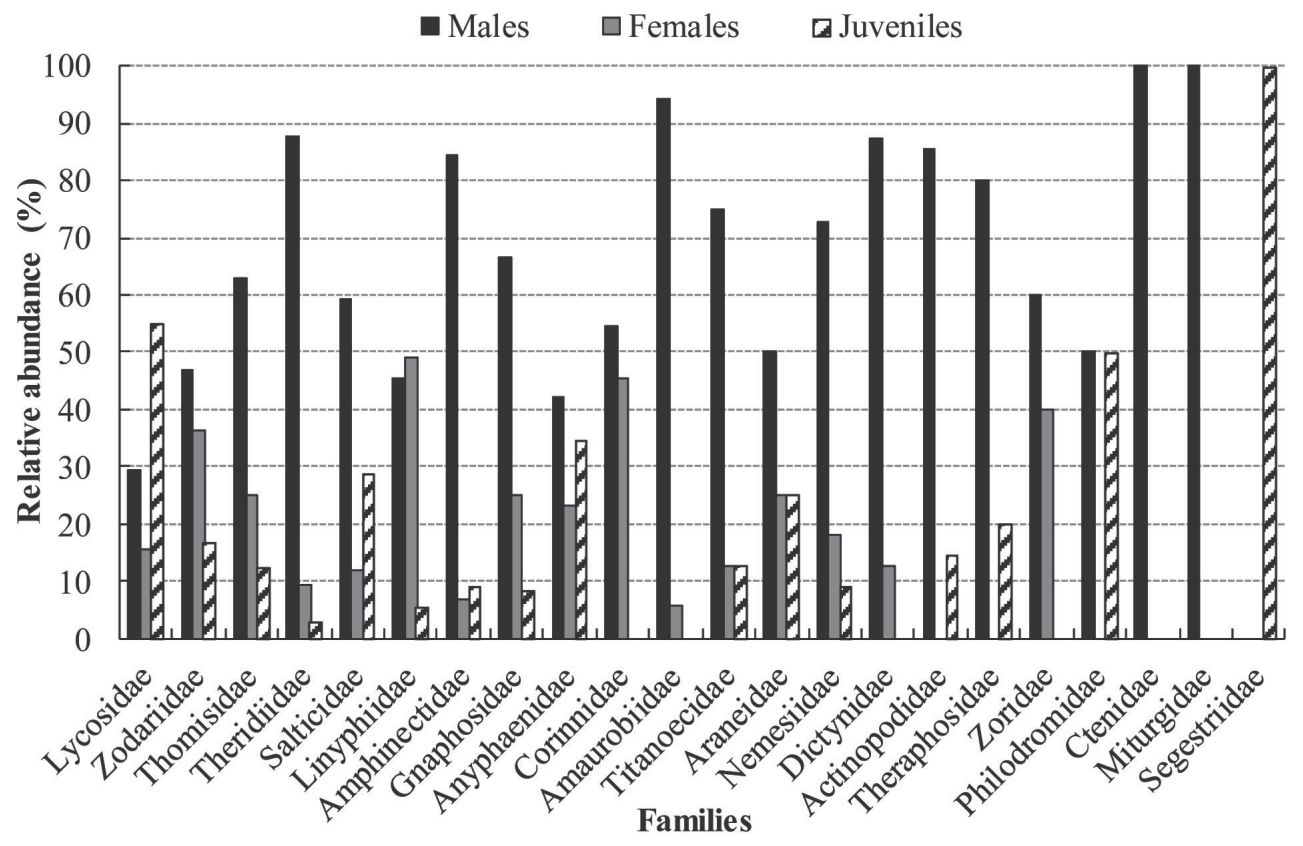

Figure 2. Relative abundance of the juveniles and adults of each family. 
to L. birabeni, and of Salticidae it was due to Salticidae sp. 1. The total number of species was highest in winter and lowest in summer. Some species were only found in one season (Table 1). When the abundance of the six most abundant species was analysed per sex (Fig. 4), it was registered that contrary to the general finding, L. birabeni females were more abundant than males particularly in summer and autumn; Thomisidae sp. 32 females were more abundant than males in spring; Steatoda sp.1 males were very abundant in spring as well as autumn; and $O$. melanopygius both sexes were almost in equal amounts during seasons.

From the total of the species registered, 13 were "singletons" (species represented by one individual in the sample) (20\% of all the species) and other 12 , "doubletons" (species represented by two individuals in the sample) (18.46\%). The observed species and the expected number of species curves reached an asymptote (Fig. 5A). Chao 1 mean was 70.99. The accumulative curve of singletons tends to decrease and of doubletons tends to stability (Fig. 5B).

\section{DISCUSSION}

The geography, vegetation, and climatic variables, amongst other factors may result in differences in the distribution of members of some groups of spiders and on habitat selection (Gerschman de Pikelin \& Schiapelli
1963; Comstock 1965; Uetz 1992). Several authors have described a greater diversity and biomass of spiders in undisturbed natural areas than in agro-ecosystems (Nyeffeler \& Benz 1987; Alderweireldt 1989; Desender et al. 1989; Heideger \& Nentwig 1989; Liljesthröm et al. 2002; Avalos et al. 2007, 2009; Beltramo et al. 2006; Almada 2010; Almada et al. 2012), such as is the semi-rural area used in this work.

The spider families found in this study represented $34 \%$ of the total of the families described in Argentina and the species, to $5.5 \%$ (World spider Catalog 2015). The families Amphinectidae, Nemesiidae, Theraphosidae, Zoridae, Ctenidae and Segestriidae were not registered in agro-ecosystems of Santa Fe (Beltramo et al. 2006; Almada et al. 2012), and neither Amphinectidae nor Nemesiidae were recorded in the ecological Reserve "E1 Pozo" (Almada 2010), before this survey. Moreover, these two families were not found in degraded woods of the humid Chaco in Corrientes province (Avalos et al. 2007). These differences might be due to the geography, type of environment, climate or the sampling technique. In relation to the sampling technique, may be differences could also be attributed to the fact that some spiders are commonly associated with ephemeral habitats such as cadavers (which are significant feeding and/or reproducing resource for other arthropods such as insects), due to their predatory or saprophagous habits (Norris 1965; Seastedt et al. 1981; Keh 1985; Smith 1986; Lord 1990; Catts \& Goff 1992).

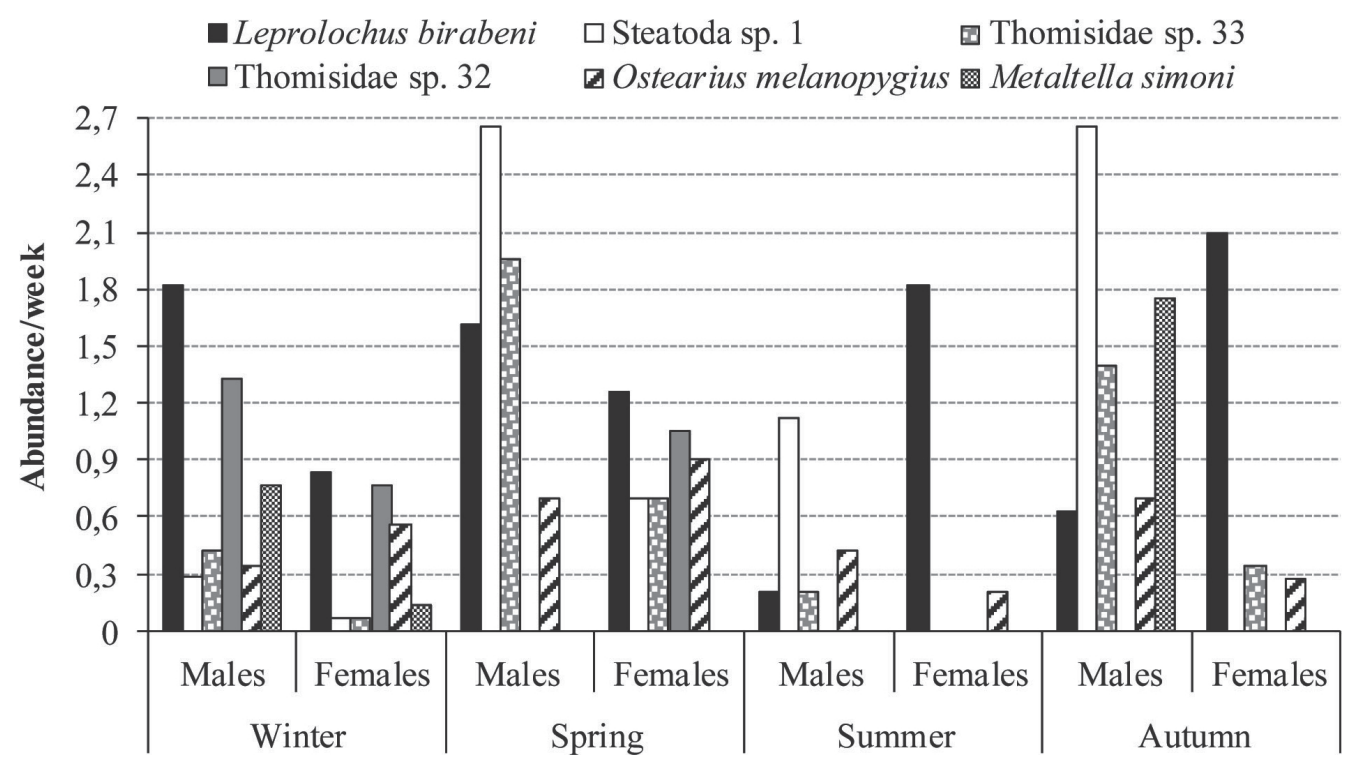

Figure 4. Density of males and females of the six most abundant species per season. 

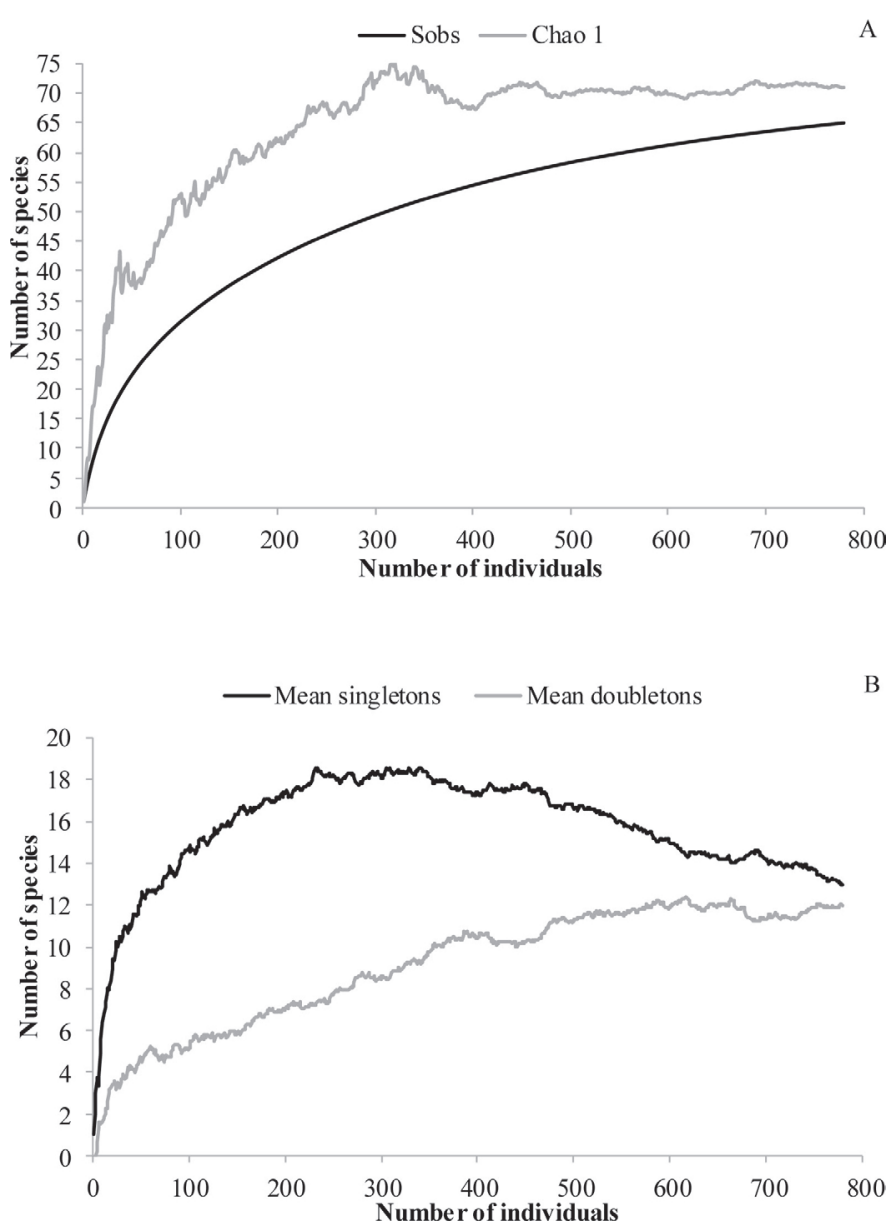

Figure 5. Species richness. A) Observed species richness (Sobs) and estimated richness for Chao 1 of the spiders of a semirural area of Bahía Blanca; B) Accumulative curves of singletons and doubletons of spiders of a semirural area of Bahía Blanca.

Regarding abundance, the families with a greatest number of individuals were Lycosidae, Zodariidae, Thomisidae, Theridiidae and Saliticidae; Lycosidae, followed by Theridiidae, had the greatest number of species. Several studies also reported Lycosidae as the most abundant family in natural areas (Rubio et al. 2008), and agro-ecosystems (Beltramo et al. 2006; Armendano \& González 2010) as well as the most abundant in the ground substrate of those disturbed environments in Argentina (Minervino 1996; Liljesthröm et al. 2002; Beltramo et al. 2006). Because they are active spiders that move above ground and under fallen leaves in search of their prey, and do not spin webs to hunt (Nyffeler \& Benz 1988). The families Zodariidae and Salticidae are active hunters who must also move to find their prey. Such find- ings could also be related to the fact that spiders can use cadavers as a refuge or hunting places (Watson 2004; Gill 2005).

Individuals were grouped into eight guilds, of which the greatest number of individuals corresponded to the ground hunters followed by specialists. This could be explained by the sampling methods as well as the type of environment. Cardoso et al. (2011) mentioned that the precise proportions per guild (and family) found are specific to the methods available. They also suggested that functional diversity is positively related with habitat complexity, with more complex habitats being more functionally diverse.

Adults were more abundant than juveniles, and adult males more abundant than females, which could be due to the sampling technique used. Furthermore, males are probably more active in their search for mates; consequently, they have a higher probability of being captured in the traps (Mineo et al. 2010; Ferretti et al. 2012). Because the highest proportion of adults and juveniles were trapped during spring, it cannot be concluded that many species have their reproductive period during that season.

The species richness was lower than that recorded in degraded woods of the humid Chaco in Corrientes (Avalos et al. 2007), but greater than that observed in agro-ecosystems of Buenos Aires (Grismado 2007; Armendano \& González 2010) and Santa Fe (Almada et al. 2012). The same factors cited for differences in developmental time and abundance may be affecting species richness. The prey availability and the risk of predation or parasitism of spiders could be other important factors influencing the species richness of spiders (Crouch \& Lubin 2000). These factors could influence species richness or other parameters of the spiders, alone or in combination with other factors (Halaj et al. 1998; Bell et al. 2001; New 2005; Spears \& MacMahon 2012; Diehl et al. 2013). In this way, the great diversity and abundance of arthropods observed (Coleoptera, Diptera, Hymenoptera, amongst other) during the decomposition and succession study, could contribute to the results found in this work.

Leprolochus birabeni (Zodariidae) was the most abundant species, which is coincident with the results reported by Pompozzi et al. (2011) for La Pampa province. These spiders belong to the specialists guild, so they capture their prey moving over the ground (Grismado et al. 2011). The second in abundance was Steatoda sp. 1 (Theridiidae), which was probably due to the activity of males (Mineo et al. 2010; Ferretti et al. 2012). Metaltella simoni (Amphinectinae), which was fifth in abundance, 
are ground hunters common in places such as cities, gardens and vacant lots (Grismado et al. 2011).

The number of singletons was lower than $50 \%$, thus it is unlikely to be underestimation of species (Colwell \& Coddington 1994) as reported in other studies (Avalos et al. 2007, 2009; Pompozzi et al. 2011). The values of Sobs and of Chao 1 were very similar and the expected number of species curve and the curve of doubletons were asymptotic, and the curve of singletons tended to decrease. This could indicate that the effort was enough and the study area was sufficiently sampled (the number of species/morphospecies of the area would not increase with the number of samplings) (Villarreal et al. 2004). This was not unexpected because the high proportion of "singletons" is a characteristic of the tropical arthropod fauna in woods and tropical and temperate savannahs (Florez 1998; Sørensen et al. 2002; Withmore et al. 2002). Such areas are characterized by a high number of species that usually exhibit low population densities or are rare (Florez 1998; Sørensen et al. 2002). Some studies have shown that seasonality influences the abundance, growth rate, and size of spiders (Gaston et al. 1993; Gasnier et al. 2002). This could be related to different factors, as mentioned above, as well as foraging and/or an increase in prey density, which can vary over the season in response to environmental conditions (Kiritani et al. 1972; Mahalakshmi \& Jeyaparvathi 2014). These factors could account, at least partially, for the increase recorded in the spider density during spring. In this study, climate variables did not affect the spider abundance differently depending on the sex and age of the spiders. The fact that some families were found in certain seasons could be due to juveniles or eggs that hibernate during those periods, as well as to some organisms having two reproductive periods and entering diapause in the adult stage (Jimenez \& Navarrete 2010).

ACKNOWLEDGEMENTS. She wishes to thank Lic. Gabriel Pompozzi and Leonela Swcherdt (Universidad Nacional del Sur) for their assistance with the taxonomic determination of individuals, to Lic. Ricardo Camina (Universidad Nacional del Sur) for his statistical advice and to the CONICET for her fellowship. This work was funded by grants from Universidad Nacional de Quilmes and Universidad Nacional del Sur.

\section{LITERATURE CITED}

Alderweireldt, M. 1989. An ecological analysis of the spider fauna (Araneae) occurring in maize fields, Italian ryegrass fields and their edge zones, by means of different multivariate techniques. Agriculture, Ecosystems \& Environment, 27: 293-306.

Almada, M. S. 2010. Primer relevamiento de arañas (Araneae) en la reserva ecológica de la ciudad universitaria "El Pozo" (Santa Fe, Argentina). Informe Técnico del Museo Provincial de Ciencias Naturales Florentino Ameghino. Biológica, (12): 61-64.

Almada, M. S., Sosa, M. A. \& González, A. 2012. Araneofauna (Arachnida: Araneae) en cultivos de algodón (Gossypium hirsutum) transgénicos y convencionales en el norte de Santa Fe, Argentina. Revista de Biología Tropical, 60: 611-623.

Armendano, A. \& González, A. 2010. Comunidad de arañas (Arachnida, Araneae) del cultivo de alfalfa (Medicago sativa) en Buenos Aires, Argentina. Revista de Biología Tropical, 58: 747-757.

Armendano, A. \& González, A. 2011a. Efecto de las arañas (Arachnida: Araneae) como depredadoras de insectos plaga en cultivos de alfalfa (Medicago sativa) (Fabaceae) en Argentina. Revista de Biología Tropical, 59: 1651-1662.

Armendano, A. \& González, A. 2011b. Spider fauna associated with wheat crops and adjacent habitats in Buenos Aires, Argentina. Revista Mexicana de Biodiversidad, 82: 1176-1182.

Avalos, G., Rubio, G. D., Bar, M. E. \& González, A. 2007. Arañas (Arachnida: Araneae) asociadas a dos bosques degradados del Chaco húmedo en Corrientes, Argentina. Revista de Biología Tropical, 55: 899-909.

Avalos, G., Damborsky, M. P., Bar, M. E., Oscherov, E. B. \& Porcel, E. 2009. Composición de la fauna de Araneae (Arachnida) de la Reserva provincial Iberá, Corrientes, Argentina. Revista de Biología Tropical, 57: 339-351.

Avalos, G., Bar, M. E., Oscherov, E. B. \& González, A. 2013. Diversidad de Araneae en cultivos de Citrus sinensis (Rutaceae) de la Provincia de Corrientes, Argentina. Revista de Biología Tropical, 61: 1243-1260.

Barnes, B. V., Zak, D. R., Denton, S. R. \& Spurr, S. H. 1998. Forest Ecology, 4th Edition. John Wiley \& Sons, Inc, New York, NY, $774 \mathrm{pp}$.

Bell, J. R., Wheater, C. P. \& Cullen, W. R. 2001. The implications of grassland and heathland management for the conservation of spider communities: a review. Journal of Zoology (London), 255: 377-387.

Beltramo, J., Bertolaccinia, I. \& González, A. 2006. Spiders of soybean crops in Santa Fe Province, Argentina: influence of surrounding spontaneous vegetation on lot colonization. Brazilian Journal of Biology, 66: 891-898.

Campo, A. \& Zapperi, P. 2010. Diferenciación espacial de las precipitaciones en la ciudad de Bahía Blanca. Contribuciones cientificas-Sociedad Argentina de Estudios Geográficos, 22: 97-105.

Campo de Ferreras, A., Hernández Moresino, S., Huamantinco Cisneros, M. \& Zapperi, P. 2004. Ocurrencia de Sudestadas en el Suroeste bonaerense. Contribuciones cientificas-Sociedad Argentina de Estudios Geográficos, 16: 45-50.

Campo, A., Ramos, B. \& Zapperi, P. 2009. Análisis de las variaciones anuales de las precipitaciones en el Suroeste bonaerense, Argentina. Actas electrónicas del 12 Congreso de Geógrafos Latinoamericanos 12: 1-12.

Catts, E. P. \& Goff, M. L. 1992. Forensic Entomology in Criminal Investigations. Annual Review of Entomology, 37: 253-272.

Centeno, N. D., Maldonado, M. \& Oliva, A. 2002. Seasonal patterns 
of arthropods occurring on sheltered and unsheltered pig carcasses in Buenos Aires Province (Argentina). Forensic Science International, 126: 63-70.

Chin, H. C., Kurahashi, H., Marwi, M. A., Jeffery, J. \& Omar, B. 2011. Opportunistic insects associated with pig carrions in Malaysia. Sains Malaysiana, 40: 601-604.

Clausen, I. H. S. 1986. The use of spiders (Araneae) as ecological indicators. Bulletin of the British Arachnological Society, 7: 83-86.

Colwell, R. K. \& Coddington, J. A. 1994. Estimating the extent of terrestrial biodiversity through extrapolation. Philosophical Transactions of the Royal Society: Biological Sciences, 345: 101-118.

Comstock, J. 1965. La araña de libros, 4ed. Comstock Publishing Associates, Ithaca, NY, 729 pp.

Colwell, R. K. 2013. EstimateS: Statistical estimation of species richness and shared species from samples. Version 9.1.0. User's Guide and application. http://viceroy.eeb.uconn.edu/estimates/EstimateSPages/EstimateS.php. Accessed on 5 June 2015.

Crouch, T. E. \& Lubin, Y. 2000. Effects of climate and prey availability on foraging in a social spider, Stegodyphus mimosarum (Araneae, Eresidae). The Journal of Arachnology, 28: 158-168.

Desales-Lara, M. A., Francke, O. F. \& Sánchez-Nava, P. 2013. Diversidad de arañas (Arachnida: Araneae) en hábitats antropogénicos. Revista Mexicana de Biodiversidad, 84: 291-305.

Desender, K., Alderweireldt, M. \& Pollet, M. 1989. Field edges and their importance for polyphagos predatory arthropods. Mededelingen Van de Faculteit Landbouwwetenschappen, Rijksuniversiteit Gent, 54: 823-833.

Diehl, E., Mader, V. L., Wolters, V. \& Birkhofer, K. 2013. Management intensity and vegetation complexity affect web-building spiders and their prey. Oecologia, 173: 579-589.

Durán-Barrón, C. G., Francke, O. F. \& Pérez-Ortiz, T. M. 2009. Diversidad de arañas (Arachnida: Araneae) asociadas a viviendas de la ciudad de México (Área metropolitana). Revista Mexicana de Biodiversidad, 80: 55-69.

Ferretti, N., Pompozzi, G., Copperi, S., González, A. \& PérezMiles, F. 2010. Arañas Mygalomorphae de la Provincia de Buenos Aires, Argentina: clave para la determinación de especies. BioScriba, 3: 15-34.

Ferretti, N., Pompozzi, G., Copperi, S., Pérez-Miles, F. \& González, A. 2012. Mygalomorph spider community of a natural reserve in a hilly system in central Argentina. Journal of Insect Science, 12: $1-16$.

Foelix, R. F. 2011. Biology of Spiders. Third edition. Oxford University Press, Ney York, NY, 432 pp.

Flórez-D., E. 1998. Estructura de comunidades de arañas (Araneae) en el departamento Del Valle, suroccidente de Colombia. Caldasia, 20: 173-192.

Gabella, J., Zapperi, P. \& Campo, A. 2010. Distribución estacional de las precipitaciones en el Suroeste bonaerense. Actas de las VIII Jornadas de Geografia Física, VIII: 87-94.

García-Rojo, A. M., Honorato, L., González, M. \& Téllez, A. 2009. Determinación del intervalo post mortem mediante el estudio de la sucesión de insectos en dos cadáveres hallados en el interior de una finca rústica en Madrid. Cuadernos de Medicina Forense, 15: 137-145.

Gasnier, T. R., Torres-Sanchez, M. P., Azevedo, C. S. \& Höfer, H. 2002. Adult size of eight hunting spider species in central Ama- zonia: temporal variations and sexual dimorphisms. Journal of Arachnology, 30: 146-154.

Gaston, H. J., Blackburn, T. M., Hammond, P. M. \& Stork, N. E. 1993. Relationships between abundance and body size: where do tourists fit? Ecological Entomology, 18: 310-314.

Gerschman de Pikelin, B. S. \& Schiapelli, R. D. 1963. Llave para la determinación de familias de arañas argentinas. Physis, 24: 43-72.

Gil, V., Zapperi, P., Campo, A., Iuorno, M. V. \& Ramborge, M. A. 2008. Análisis de las precipitaciones de otoño y primavera en el Suroeste bonaerense. Actas de las VII jornadas Nacionales de Geografia Física, 42: 149-158.

Gill, G. J. 2005. Decomposition and arthropod succession on above group pig carrion in rural Manitoba. Technical report $n^{\circ} 6$. Department of Entomology, University of Manitoba, Winnipeg, Manitoba, $174 \mathrm{pp}$.

Goff, M. L. 2009. Early post-mortem changes and stages of decomposition in exposed cadavers. Experimental \& Applied Acarology, 49: 21-36.

Goloboff, P. A. 1995. A revision of the South American spiders of the family Nemesiidae (Araneae, Mygalomorphae). Part I: species from Peru, Chile, Argentina, and Uruguay. Bulletin of the American Museum of Natural History, 224: 1-189.

González, A., Liljesthröm, G., Minervino, E., Castro, D., González, S. \& Armendano, A. 2009. Predation by Misumenops pallidus (Araneae: Thomisidae) on insect pests of soybean cultures in Buenos Aires Province, Argentina. The Journal of Arachnology, 37: 282-286.

Greene, A., Breisch, N. L., Boardman, T., Pagac, B. B. Jr., Kunickis, E., Howes, R. K. \& Brown, P. V. 2009. The Mediterranean Recluse Spider, Loxosceles rufescens (Dufour): an abundant but cryptic inhabitant of deep infrastructure in the Washington, D.C. Area (Arachnida: Araneae: Sicariidae). American Entomologist, 55: $158-167$.

Grismado, C. J. 2007. Comunidades de Arañas de la Reserva Natural Otamendi, Provincia de Buenos Aires. Riqueza especifica y diversidad. Thesis of B. Sc. Departamento de Ciencias Biológicas, Universidad CAECE, Buenos Aires, 95 pp.

Grismado, C. J., Crudele, I., Damer, L., López, N., Olejnik, N. \& Trivero, S. 2011. Comunidades de arañas de la Reserva Natural Otamendi, Provincia de Buenos Aires. Composición taxonómica y riqueza específica. Biológica, (14): 7-48.

Hatley, C. L. \& Macmahon, J. A. 1980. Spider community organization: seasonal variation and the role of vegetation architecture. Environmental Entomology, 9: 632-639.

Heidger, C. \& Nentwing, W. 1989. Augmentation of beneficial arthropods by strip-management. 3. Artificial introduction of a spider species which preys on wheat pest species. Entomophaga, 34: 511-522.

Jiménez, M. L. \& Navarrete, J. G. 2010. Fauna de arañas del suelo de una comunidad árida-tropical en Baja California Sur, México. Revista Mexicana de Biodiversidad, 81: 417-426.

Halaj, J., Ross, D. W. \& Moldenkel, A. R. 1998. Habitat structure and prey availability as predictors of the abundance and community organization of spiders in Western Oregon forest canopies. The Journal of Arachnology, 26: 203-220.

Keh, B. 1985. Scope and applications of forensic entomology. Annual Review of Entomology, 30: 137-154. 
Cramer, K. L. 2015. Activity patterns of a synanthropic population of the brown recluse spider, Loxosceles reclusa (Araneae: Sicariidae), with observations on feeding and mating. Journal of Arachnology, 43: 67-71.

Kiritani, K., Kawahara, S., Sasaba, T. \& Nakasuji, F. 1972. Quantitative evaluation of predation by spiders on the green rice leaf hopper, Nephotettix cincticeps Uhler, by a sight count method. Researches on Population Ecology, 13: 187-200.

Kwon, T-S., Lee, C. M., Kim, T. W., Kim, S-S. \& Sung, J. H. 2014. Prediction of abundance of forest spiders according to climate warming in South Korea. Journal of Asia-Pacific Biodiversity, 7: e133-e155.

Liljesthröm, G., Minervino, E., Castro, D. \& González, A. 2002. Ecology, behavior and bionomics: la comunidad de arañas del cultivo de soja en la provincia de Buenos Aires, Argentina. Neotropical Entomology, 31: 197-210.

Lima Silveira, A. 2009. Primeiro registro sinantrópico de Loxosceles laeta (Nicolet, 1849) (Araneae, Sicariidae) no Município do Rio de Janeiro, Estado do Rio de Janeiro. Revista da Sociedade Brasileira de Medicina Tropical, 42: 723-726.

Lord, W. D. 1990. Case histories of use of insects in investigations, pp. 9-37. In: E. P. Catts and N. H. Haskell (Eds.). Entomology and death, a procedural guide Ed. 1. Joyce's Print Shop, Clemson, SC.

Lubin, Y. D. 1978. Seasonal abundance and diversity of web-building spiders in relation to habitat structure on Barro Colorado Island, Panama. Journal of Arachnology, 6: 31-51.

Maelfait, J. P., Jocque, R., Baert, L. \& Desender, K. 1990. Heathland management and spiders. Acta Zoologica Fennica, 190: 261166.

Mahalakshmi, R. \& Jeyaparvathi, S. 2014. Diversity of spider fauna in the cotton field of Thailakulam, Virudhunagar District, Tamil Nadu, India. The Journal of Zoology Studies, 1: 12-18.

McNabb, D. M., Halaj, J. \& Wise, D. H. 2001. Inferring trophic positions of generalist predators and their linkage to the detrital food web in agroecosystems: a stable isotope analysis. Pedobiologia, 45: 289-297.

Meffe, G. K. \& Carroll, C. R. 1994. Principles of Conservation Biology. Sinauer Associates, Sunderland, MA, 779 pp.

Mineo, M. F., Del-Claro, K. \& Brescovit, A. D. 2010. Seasonal variation of ground spiders in a Brazilian Savanna. Zoologia, 27: 353-362.

Minervino, E. 1996. Estudio biológico y ecobiológico de arañas depredadoras de plagas de la soja. Thesis of Doctor. Universidad Nacional de La Plata, La Plata, 130 pp.

Morrone, J. J. 2002. Presentación sintética de un nuevo esquema biogeográfico de América Latina y el Caribe. Monografías Tercer Milenio SEA, 2: 267-275.

New, T. R. 2005. Invertebrate Conservation and Agricultural Ecosystems. Cambridge University Press, Cambridge, UK, 349 pp.

Norris, K. R. 1965. The bionomics of blow files. Annual Review of Entomology, 10: 47-68.

Nyffeler, M. \& Benz, G. 1987. Spiders in natural pest control: a review. Journal of Applied Entomology, 103: 321-339.

Nyeffeler, M. \& Benz, G. 1988. Feeding ecology and predatory importance of wolf spiders (Pardosa sp) (Araneae, Lycosidae) in winter wheat fields. Journal of Applied Entomology, 106: 123-134.
Pinkus-Rendón, M. A., León-Cortés, J. L. \& Ibarra-Núñez, G. 2006. Spider diversity in a tropical habitat gradient in Chiapas, Mexico. Diversity and Distributions, 12: 61-69.

Pompozzi, G. A., Tizón, F. R. \& Pelaéz, D. V. 2011. Effects of different frequencies of fire on an epigeal spider community in Southern Caldenal, Argentina. Zoological Studies, 50: 718-724.

Ramirez, M. J. 1999. Orden Araneae. En "El ABC en la Determinación de artrópodos I”, pp. 39-59. In: F. A. Crespo, M. S. Iglesias \& A. C. Valverde (eds.). CCC Educando, Buenos Aires, BS. AS.

Rubio, G. D., Corronca, J. A. \& Damborsky, M. P. 2008. Do spider diversity and assemblages change in different contiguous habitats? A case study in the protected habitats of the humid Chaco ecoregion, Northeast Argentina. Environmental Entomology, 37: 419-430.

Rubio, G. D. \& Moreno, C. E. 2010. Orb-weaving spider diversity in the Iberá Marshlands, Argentina. Neotropical Entomology, 39:496-505.

Scheidler, M. 1990. Influence of habitat structure and vegetation architecture on spiders. Zoologischer Anzeiger, 225: 333-340.

Seastedt, T. R., Mameli, L. \& Gridley, K. 1981. Arthropod use of invertebrate carrion. American Midland Naturalist, 105: 124-129.

Silva de Miranda, G. \& Ponce de Leão Giupponi, A. 2011. A new synanthropic species of Charinus Simon, 1892 from Brazilian Amazonia and notes on the genus (Arachnida: Amblypygi: Charinidae). Zootaxa, 2980: 61-68.

Smith, K. G. V. 1986. A manual of forensic entomology. The Trustees of the British Museum (Natural History), London, 205 pp.

Sørensen, L. L., Coddington, J. A. \& Scharff, N. 2002. Inventorying and estimating subcanopy spider diversity using semiquantitative sampling methods in an Afromontane Forest. Environmental Entomology, 31: 319-330.

Spears, L. R. \& MacMahon, J. A. 2012. An experimental study of spiders in a shrub-steppe ecosystem: the effects of prey availability and shrub architecture. Journal of Arachnology, 40: 218-227.

Sudhikumar, A. V., Mundackatharappel, J. M., Sunish, E. \& Sebastian, P. A. 2005. Seasonal variation in spider abundance in Kuttanad rice agroecosystem, Kerala, India (Araneae). European Arachnology. Acta zoologica bulgarica, Suppl. (1): 181-190.

Taylor, R. J. \& Doran, N. 2001. Use of terrestrial invertebrates as indicators of the ecological sustainability of forest management under the Montreal Process. Journal of Insect Conservation, 5: 221-231

Tsai, Z. I., Huang, P. S. \& Tso, I. M. 2006. Habitat management by aboriginals promotes high spider diversity on an Asian tropical island. Ecography, 29: 84-94.

Turnbull, A. L. 1973. Ecology of the true spiders (Araneomorphae). Annual Review of Entomology, 18: 305-348.

Uetz, G. W. 1991. Habitat structure and spider foraging, pp. 325-348. In: S. S Bell, E. D. Mccoy and H. R. Mushinsky (Eds.). Habitat structure; the Physical Arrangement of Objects in Space. Chapman and Hall, London.

Uetz, G. W. 1992. Foraging strategies of spiders. Trends in Ecology and Evolution, 7: 155-159.

Watson, E. J. 2004. Faunal succession of necrophilous insects associated with high-profile wildlife carcasses in Louisiana. $\mathrm{PhD}$ thesis. Louisiana State University and Agricultural and Mechanical College, Baton Rouge, LA, vii+212 pp. 
Villareal, H., Álvarez, M., Córdoba, S., Escobar, F., Fagua, G., Gast, F., Mendoza, H., Ospina, M. \& Umaña, A. M. 2004. Manual de métodos para el desarrollo de inventarios de biodiversidad. Programa de inventarios de Biodiversidad. Instituto de Investigación de Recursos Biológicos Alexander von Humboldt, Bogotá, Colombia, $236 \mathrm{pp}$.

Weeks, R. D. Jr. \& Holtzer, T. O. 2000. Habitat and season in structuring ground-dwelling spider (Araneae) communities in a shortgrass steppe ecosystem. Environmental Entomology, 29: 1164-1172.

Willett, T. R. 2001. Spiders and other arthropods as indicators in oldgrowth versus logged redwood stands. Restoration Ecology, 9: 410-420.

Wise, D. H., Snyder, W. E. \& Tuntibunpaku, P. 1999. Spiders in decomposition food webs of agroecosystems: theory and evidence.
Journal of Arachnology, 27: 363-370.

Whitmore, C., Slotow, R., Crouch, T. E. \& Dippenaar-Schoeman, A. S. 2002. Diversity of spiders (Araneae) in a savanna reserve, Northern Province, South Africa. Journal of Arachnology, 30: 344-356.

World Spider Catalog. 2015. Version 16. Natural History Museum Bern. http://www.wsc.nmbe.ch/. Accessed on 30 May 2015.

Zanetti, N. I. 2013. Estudio bionómico de la coleópterofauna de interés forense bajo condiciones naturales y controladas en el área de Bahía Blanca, Prov. de Buenos Aires, Argentina. Tesis de Doctorado. Universidad Nacional del Sur, Bahía Blanca, Argentina, viii+291 pp.

Zanetti, N. I., Visciarelli, E. C. \& Centeno, N. D. 2015. Associational patterns of scavenger beetles to decomposition stages. Journal of Forensic Sciences 60: 919-927. 